\title{
RISK MANAGEMENT IN SMALL FAMILY FARMS IN POLAND
}

Sebastian Stepien², PhD, Associate Professor; Jan Polcyn ${ }^{3}$, PhD, Associate Professor ${ }^{1}$ Poznan University of Economics and Business, ${ }^{2}$ Stanislaw Staszic University of Applied Sciences in Pila

\begin{abstract}
Small farms play an important role in the sustainable development of rural areas. However, the data indicate that their number has been gradually decreasing. The reason for this reduction is the low profitability of production, combined with the uncertainty created by the high risk of agricultural production. In this context, it is important to create an appropriate risk management strategy that will ensure stable income and allow continuing agricultural production. The aim of the publication is to assess the activities of small farms in terms of price and production risk management. The paper also presents a relationship between the range of instruments used and the basic characteristics of farms. Finally, the agricultural households are assessed from the point of view of the methods of production planning. The article uses unpublished data from a questionnaire survey conducted on a group of 710 small farms in Poland at the turn of $2017 / 2018$. The results of the analysis indicate that the level of risk management in the studied group is very small. The only commonly used instrument included obligatory insurance of production facility. Every third producer insured crops, and every fourth diversified production. The remaining methods were used very rarely. In addition, most farms used only one or two risk management instruments. A positive correlation was found between the number of the management tools used and the level of manager's education, the size of agricultural area, the level of estimated income and the share of goods sold on the market.
\end{abstract}

Key words: small farms, risk management, Poland, questionnaire survey.

JEL code: D81, Q12.

\section{Introduction}

Agricultural activity, like any other economic activity, is accompanied by uncertainty and the consequences of decisions made by the agricultural producer may be at risk. The relationship between uncertainty and risk seems clear, as both phenomena are characterized by a high degree of random variation, and the level of uncertainty and risk depends to a large extent on how extensive information about the market we have. In fact, we never have full information and, as a result, uncertainty and risk are permanent elements of the functioning of business entities. It can also be said that in agriculture information is highly imperfect (Bocker A., Herrmann R., 2004; Sheldon I.M., 1996), hence the sector is particularly exposed to various risks. In practice, the two most common types of risk are price risk, due to the low elasticity of supply and demand in the agricultural sector, as well as the biological nature of production, which leads to price fluctuations (eg. on the pig market) and production risk related to external factors (mainly weather) influencing achieved effects ${ }^{4}$ (Nather M., Theuvsen L., 2012). They cause high income volatility in both the one-year and the many-year periods, which may result in farmers abstaining from investments or optimal use of resources, and eventually lead to withdrawal from the market. Only in 2010-2016, the number of farms in Poland decreased by 100,000 , including the smallest ones, to 5 ha of UAA, by 55 thousand (Statistical Yearbook ... 2017), mainly due to low profitability of production. The latter number is worried above all taking into account the fact, that small farms plays an exceptional role in the sustainable development of rural areas. Their contribution to the creation of social and environmental balance in the countryside is particularly important (Czyzewski A., Stepien S., 2013; Zegar J.S., 2012), but this requires a guarantee of maintaining relatively favourable and stable income relations. Moreover, as emphasized by T. Wojewodzic (2014), for the implementation of environmental functions by small farms it

\footnotetext{
1 The paper was written as a part of the project titled "The role of small farms in the sustainable development of agri-food sector in the coutries of Central and Eastern Europe", financed by the Polish National Agency for Academic Exchange (agreement no. PPI/APM/2018/1/00011/DEC/1).

${ }^{2}$ Sebastian Stepien, Poznan University of Economics and Business, Department of Macroeconomics and Agricultural Economics, Al. Niepodleglosci 10, 61-875 Poznan, Poland. Tel. +48 696411 391, e-mail: sebastian.stepien@ue.poznan.pl

3 Jan Polcyn, Stanislaw Staszic University of Applied Sciences in Pila, Faculty of Economics, ul. Podchorazych 10, 64-920 Pila, Poland. Tel. +48 666 346 901, email: jan.polcyn@gmai.com

${ }^{4}$ Other risks include institutional (administrative) risk related to the volatility of agricultural policy; financial risk refering to a case of excessive use of external sources of financing (eg. increase in interest rate); personal risk, such as, for example, farmer's health status (illness, accidents).
} 
is necessary to conduct active agricultural activity (otherwise, the so-called environmental costs of land abandonment, i.e. uncontrolled development of weeds, could arise). In this context, an appropriate risk management strategy in agricultural activity becomes very important, the effects of which will positively affect the development of agricultural holdings, including small food producers.

In practice, a farm has a choice of four risk minimization strategies in agricultural production, namely: risk avoidance, referring to the withdrawal from activities exposed to loss; stopping the risk, by financing loss inside the holding; risk control, including actions to prevent the negative effects of price and production volatility; and risk transfer, i.e. the transfer of its part to another entity (Klimkowski C., 2007). The first of these methods is undoubtedly the most effective, however, it leads to the loss of long-term income from a given activity. It is also difficult to apply due to the low flexibility of the assets involved in agricultural production and large exit barriers. Stopping the risk, on the other hand, requires large financial capital or obtaining credit/loan in case of declining profitability of farming, which is difficult for many smaller farms to meet. As part of risk control, one can mention diversification of activities, participation in coordinated production systems (groups of agricultural producers, cooperatives), transactions on the commodity exchange. Finally, as part of the risk transfer, an insurance contract is agreed between the agricultural holding and the financial institution (Anton J., 2011). The aim of the publication is to assess the activities of small farms in terms of price and production risk management. It is about indicating which instruments are used by the farms and how many selected methods they implement. The work focuses on the last two of the aforementioned strategies, i.e. control and transfer of risk, which, according to the authors, are the most effective for those small farms that plan to continue farming. The article also presents the relationship between the range of instruments used and the basic characteristics of the farm - age, education of manager, size of farm and type of production, estimated income and share of agricultural production on the market. At the end, the agricultural households are assessed from the point of view of the method (sources) of production planning. The way in which farms plans production and what information they possess has a significant impact on future economic results and, combined with selected risk management instruments, is a comprehensive strategy for minimizing losses/maximizing effects. The publication uses unpublished data from a questionnaire survey ${ }^{5}$ conducted on a group of 710 small farms in Poland at the turn of $2017 / 2018$. The data was collected by direct interviews conducted by specialized agricultural advisors cooperating with farms under the FADN system. The target group was divided into farms participating in the agricultural accounting system and the so-called "twin farms", similar in size and structure to FADN holdings. The spatial scope of the study concerned all 16 regions in Poland (voivodships). Since there is No unambiguous definition of a small farm, for the purposes of the study its definition was adopted on the basis of two criteria: 1) standard output ${ }^{6}$ (SO) below or equal to 15.000 euro, 2) as a "semisubsistence farm" where less than $50 \%$ of the agricultural output is sold, with the remainder being consumed within the farm household. A simple descriptive statistics and average values were used to describe the structure of the studied group and the relationship between particular variables. Due to the originality of the data, the work is innovative and the collected information has applicative value, for example in the context of policy for small farms.

\footnotetext{
${ }^{5}$ The presented analysis is part of a wider study on the sustainability and food security of small farms in the countries of Central and Eastern Europe.

6 Standard output is the average monetary value of the agricultural output at farm-gate price, in euro per hectare or per head of livestock. There is a regional

SO coefficient for each product, as an average value over a reference period of 5 years. The sum of all the SO per hectare of crop and per head of livestock in a farm is a measure of its overall economic size.
} 


\section{Research results and discussion}

Part of a wider survey of small farms was to obtain information on risk management. One of the questions addressed to respondents concerned the method of production and/or price risk management in their agricultural holding. The results indicate that out of the 710 small farms surveyed, the largest group - 352 units - used only one selected method of risk reduction in agricultural production (for the most of them it was an obligatory insurance of production facilities). 244 farms used 2 risk management strategies, 68 - 3 strategies, and 17 - 4. The choice of 5 or 6 answers did not appear even once (Table 1). At the same time, 29 entities did not secure any of the methods mentioned in the question

Table 1

The structure of small farms in Poland, by form of risk management and the number of methods used (results of questionnaire)

\begin{tabular}{|c|c|c|c|c|c|}
\hline $\begin{array}{c}\text { Method of price/ } \\
\text { production risk } \\
\text { management }\end{array}$ & $\begin{array}{l}\text { Number } \\
\text { of farms }\end{array}$ & Percentage* & $\begin{array}{l}\text { Number of } \\
\text { methods used }\end{array}$ & $\begin{array}{l}\text { Number } \\
\text { of farms }\end{array}$ & Percentage \\
\hline $\begin{array}{l}\text { Insurance of farm } \\
\text { buildings and } \\
\text { machinery }\end{array}$ & 649 & $91.4 \%$ & $\mathbf{0}$ & 29 & $4.1 \%$ \\
\hline $\begin{array}{l}\text { Crops insurance against } \\
\text { weather risk }\end{array}$ & 223 & $31.4 \%$ & 1 & 352 & $49.6 \%$ \\
\hline Sales contracting & 35 & $4.9 \%$ & 2 & 244 & $34.4 \%$ \\
\hline $\begin{array}{l}\text { Membership in producer } \\
\text { group/ } \\
\text { cooperative }\end{array}$ & 30 & $4.2 \%$ & 3 & 68 & $9.6 \%$ \\
\hline $\begin{array}{l}\text { Transactions on } \\
\text { commodity exchange }\end{array}$ & 6 & $0.8 \%$ & 4 & 17 & $2.4 \%$ \\
\hline $\begin{array}{l}\text { Diversification of } \\
\text { production }\end{array}$ & 169 & $23.8 \%$ & 5 & 0 & $0.0 \%$ \\
\hline $\begin{array}{l}\text { None of mentioned } \\
\text { above }\end{array}$ & 29 & $4.1 \%$ & 6 & 0 & $0.0 \%$ \\
\hline
\end{tabular}

* Percentages do not add up to 100 due to the possibility of choosing more than 1 answer.

Source: authors' calculations based on own questionnaire survey

Due to legal requirements, the most commonly method used to secure agricultural production was an insurance of machines and farm buildings (related mainly with such random events as fire, hurricane and flood), and second place belonged to an insurance against weather risks. While the first of these methods was indicated by the overwhelming majority of farms (649 responses, which means that not all producers fulfilled the statutory obligation), in the second case only slightly more than $30 \%$ of respondents. In the future, however, one can expect an increase in interest in insurance, as they are becoming a more and more popular tool for risk management, including risk of fluctuating, unstable income. Such instruments on a large scale are used, for example, in the United States (Goodwin B.K., 2010), and in recent years also in the European Union, along with the introduction of the so-called Income Stabilization Tool (Tropea F., 2016). They are also increasingly used among small, family farms in developing countries (Poole N., 2017), as well as in China (Jian W., Rehman A., 2016). In the long term the widespread adoption of this instrument for small agricultural producers will be associated with economic availability, which requires state involvement in co-financing the system. With current income relations, the majority of small farms in Poland are unable to bear the additional cost of the policy and resign from this solution (Kobus P., 2013)

As for the other forms of risk management, almost every fourth farmer diversified production in order to spread the risk, e.g. price fluctuations or poor crops. The other methods of risk management were used by a very small group of the agricultural producers - less than $5 \%$ used contracting for the sale of agricultural products, slightly more than $4 \%$ belonged to a producer group or cooperative, and less than $1 \%$ contained transactions on the commodity exchange. In the latter case, an equally low result was also obtained for observations in Germany. Local farmers prefer the contracting system as a form of hedging 
against price fluctuations expecting that their marketing partners will use more complicated stock exchange operations (Theuvsen L., 2013).

Interesting results are provided by a description of the basic characteristics of agricultural holdings. It turns out that there is some relation between the number of methods used to manage production and price risks and such variables as the level of education of the agricultural producer, the size of the farm and the type of production (Table 2). The more educated the owner of the farm, and therefore the more comprehensive the knowledge, the more risk mitigation strategies are used. A similar positive relation applies to the area of agricultural land. This may be explained by the fact that the larger the holding is, the greater the share of income from agricultural production in the total income of the household and the greater part of commodities goes to the market (which is also confirmed by the survey data). In the group of farms that do not use any risk management strategy, on average about half of the produced production goes to the market, the second part is dedicated to self-supply.

Table 2

\section{Basic characteristics of small farms in Poland in relation to the number of methods used for risk management (results of questionnaire)}

\begin{tabular}{|l|c|c|c|c|c|}
\hline \multirow{2}{*}{ Characteristics } & \multicolumn{2}{|c|}{ Number of methods of risk management used in farm } \\
\cline { 2 - 6 } & 0 & 1 & 2 & 3 & 4 \\
\hline Age & 51.5 & 48.7 & 48.5 & 45.0 & 51.0 \\
\hline Index of education* & 4.3 & 4.6 & 4.7 & 5.1 & 5.4 \\
\hline Farm size (ha UAA) & 12.2 & 13.2 & 14.5 & 17.3 & 17.6 \\
\hline $\begin{array}{l}\text { Dominant type of production** } \\
\text { (percentage of all farms) }\end{array}$ & $7(38 \%)$ & $7(33 \%)$ & $1(41 \%)$ & $1(57 \%)$ & $1(65 \%)$ \\
\hline $\begin{array}{l}\text { Share of agricultural income in total } \\
\text { income of household }\end{array}$ & $72.9 \%$ & $79.8 \%$ & $84.4 \%$ & $87.5 \%$ & $88.9 \%$ \\
\hline $\begin{array}{l}\text { Share of agricultural production sold on } \\
\text { the market }\end{array}$ & $52.0 \%$ & $59.9 \%$ & $68.2 \%$ & $73.1 \%$ & $72.8 \%$ \\
\hline $\begin{array}{l}\text { Estimated monthly income per one } \\
\text { member of household (PLN) }\end{array}$ & 784 & 826 & 898 & 922 & 1256 \\
\hline
\end{tabular}

*Average of the following classes: 1 - No education 2 - primary, 3 - secondary, 4 - vocational, 5 - general 6 -higher bachelor degree, 7 - higher master degree.

** 1 - field crops; 7 - mixed production (No dominant of animals of crops production).

Source: authors' calculations based on own questionnaire survey.

On the opposite side, on farms using 4 different forms of risk reduction, almost $3 / 4$ of production is allocated for sale, and only slightly more than $1 / 4$ goes to the needs of the family. Hence as a result of unforeseen random events the risk of losing the main source of income in this group of ouseholds is higher. Therefore, an appropriate strategy is needed to counteract the negative effects of these situations. All the more so because there is a connection between an increase in the area of arable land and a rise in a production specialization level (in our case it is a specialization in field crops), and therefore the use of diversification of agricultural activity as a risk management method loses its importance (Stepien S., 2007).

In addition to the mentioned relation, one more was observed - the higher income per member of the household corresponds to the greater number of applied risk management strategies. One may wonder about the cause-and-effect relationship, but it would require a broader analysis that goes beyond the scope of the article. According to the authors, higher incomes are a dependent variable in relation to the specialization and scale of production (in the case of crop production inseparable from the area of arable land). In this situation, the use of risk management tools is primarily a direct consequence of the decision to expand business, not the fact of having more capital, although its lack may, for example, limit the farm's ability to obtain insurance (Lorant A., Farkas M.F., 2015). Moreover, at a higher production scale, losses resulting from negative events (e.g. unfavourable climatic conditions) are more intense, which explains why the farmer becomes more willing to use selected forms of risk reduction. Finally, if we take into account 
the division of farms into production types, two of them dominate - field crops and mixed production. In the first case, the number of risk management methods applied is higher (minimum 2), while in farms with a mixed production a result is 0 or 1 . The relation between farm specialization and the farmer's attitude to risk management is confirmed again.

Another important aspect in the context of risk reduction in production, associated primarily with cyclical and/or seasonal fluctuations in prices of agricultural commodities, refers to the assessment of business planning. In the literature, we can meet four approaches in this subject, taking into account the impact of price expectations on future decisions of producers. These are naive, adaptive, quasi-rational and rational expectations (Tomczyk E., 2011; Irwin S.H., Threan C.S., 1994). In the first case, it is assumed that future values of demand, supply and prices will be the same as recently observed. This attitude usually leads to wrong decisions. Due to changes in the above-mentioned values over time, there is a discrepancy between market conditions and the producer's decisions. In adaptive expectations, decisions are adjusted accordingly to the recent error, which allows avoiding mistakes made recently, but does not guarantee their avoidance in the event of other, previously unknown circumstances. The basis for quasi-rational expectations includes predictions based on time series of relevant variables. If the data is properly selected and the analysis is methodologically correct, then there is a high probability of making the right decisions. Finally, rational expectations are coherent and convergent with the anticipated market situation regarding the demand and supply of a given good. In this case, extensive knowledge of market conditions and access to reliable information is necessary.

From the point of view of the efficiency of risk management, it is advisable to follow rational or quasirational expectations. The level to which they will be used depends to a large extent on the costs associated with obtaining information. When new information is expensive or difficult to access, producers will use naive expectations. However, because the ability to acquire and process information is an individual human characteristic (which results from differences in intellect, education, experience, etc.), the expectations of individual farms will be strongly diversified, which is confirmed by the results of the analysis carried out in the US by J.P. Chavas (1999). The author indicates that over $70 \%$ of producers in their decisions are guided by quasi-rational or adaptive expectations. Fully rational units account for approx. 20 \%, and on the other hand, over $7 \%$ of households behave naively, assuming market conditions such as previously observed in their predictions. Similar research took place in Poland by A. Szemberg (1997). The results show that most agricultural producers do not see the impact of demand on price changes assuming that the increase in production will always lead to an increase in sales revenues (naive expectations). Therefore, they assume that in the future purchase prices and their relations will be at the same level as at the moment of making decisions. Meanwhile, due to the relative low elasticity of food demand, the increase in supply leads to a price drop more than proportionally. On a macroeconomic scale, such a situation occurs in the period of above-average crops, which leads to the so-called fertility calamity (overproduction crisis).

Referring the above information to the results of the survey, it can be stated that in the case of small farms, their decisions are far from reasonable. As many as $31 \%$ of the respondents do not create any plans for their activities, and another $42 \%$ plan production in relation to the current market situation. Less than $15 \%$ of farmers use supporting information from colleagues/neighbours, and only every 13 th farm uses stock market forecasts to plan future operations, i.e. behaves rationally. This may suggest the lack of sufficient economic knowledge among the producers, although in comparison with the question about the source of agricultural information, such a result may come as a surprise. Almost $80 \%$ of the respondents use the services of an agricultural adviser, more than half declare that they read specialist press and almost 
half participate in various types of courses and training. It could be concluded that either the level of knowledge transferred is modest or the perception of information is low.

\section{Conclusions}

On the basis of the assessment of price and production risk management among the group of small farms in Poland, the following conclusions can be made.

1) The data indicate that the level of awareness of risk management among small farms in Poland is low, as evidenced by the small number of methods used for this purpose, and the tools used are limited to the simplest and most common ones.

2) Most households have insured buildings and machinery (partly mandatory), every third insured crops, and nearly one in four diversified production. Other methods, such as contracting, sales within a producer group/cooperative or transactions on the commodity exchange, turned out to be not popular.

3) The reasons for the low involvement of small agricultural producers in the development of risk management strategies can be attributed to: lack of knowledge on the subject, lack of capital necessary e.g. for the purchase of insurance policy, lack of interest due to small scale of agricultural production and potentially small losses or lack of trust to financial institutions (in the case of insurance and stock exchange transactions), purchasers/intermediaries (in the case of contracting contracts), other agricultural producers (in the case of producer groups/cooperatives).

4) Proper planning is necessary for effective risk management in agricultural production. Meanwhile, the data indicate that the majority of respondents either do not create plans at all or plan to produce ad hoc without a thorough analysis of the market situation. Only a small part admitted that they take into account market analyses when making production decisions. This situation is not improved by the use of consultancy services, participation in courses/trainings or reading professional magazines;

5) The level of use of risk management instruments is not the same in the surveyed group. Higher engagement occurs in case of larger farms, with higher income per family member, higher market share, managed by a more educated person.

6) From the point of view of the economic, social and environmental sustainability of rural areas, the existence of small farms is crucial. To maintain their continuity, it is necessary to ensure relatively stable conditions for their development, in which the risk management strategy plays an important role. In Poland, in relation to small farms, such solutions would be connected with launching mechanisms strengthening the farmer's position in the food chain, eg setting up local food markets, introducing incentives for farmers' cooperation, for example in the form of tax relief, preferential support schemes, special programs under the second pillar of the Common Agricultural Policy. Due to the low level of participation, as well as education of small agricultural producers, a greater transfer of knowledge is necessary. A large role in this task should fall to agricultural advisory centers, as the closest to a farmer, as well as institutions related to agriculture and universities.

\section{Bibliography}

1. Anton, J. (2011). Risk Management in CAP Reform: Policy Insight from OECD Studies (presentation). Seminar on "Risk Management under the Reformed CAP", Warsaw, December.

2. Bocker, A., Herrmann, R. (2004). Food Quality, Imperfect Information and the Role of Markets and the State. Agrarwirtschaft, No. 53, pp. 301-302.

3. Central Statistical Office (2017). Statistical Yearbook of Agriculture. Warsaw, p. 107.

4. Chavas, J.P. (1999). On the Economic Rationality of Market Participants: The Case of Expectations in the U.S. Pork Market. Journal of Agricultural and Resource Economics, No. 24, pp. 19-37.

5. Czyzewski, A., Stepien, S. (2013). Ekonomiczno-społeczne uwarunkowania zmian paradygmatu rozwoju rolnictwa drobnotowarowego w swietle ewolucji Wspolnej Polityki Rolnej. Problems of Small Agricultural Holdings, no. 2, pp. 25-39. 
6. Goodwin, B.K. (2010). Countercyclical Payments That Mitigate Income or Revenue Variability: Are They Effective? North Carolina State University, Raleigh (typescript).

7. Irwin, S.H., Threan, C.S. (1994). Rational Expectations in Agriculture? A Review of the Issues and the Evidence. Review of Agricultural Economics, No. 16, pp. 133-158.

8. Jian, W., Rehman, A. (2016). Risk Management in Agriculture: Theories and Methods. Science Publishing Group, New York, pp. 19-30.

9. Klimkowski, C. (2007). Innowacyjne instrumenty ubezpieczenia rolnictwa. Komunikaty, Raporty, Ekspertyzy, no. 524, Instytut Ekonomiki Rolnictwa i Gospodarki Zwnosciowej, Warsaw, p. 13.

10.Kobus, P. (2013). Ryzyko wystepujace w produkcji roslinnej, metody jego pomiaru. In: Czynniki i mozliwosci ograniczenia ryzyka w produkcji roslinnej poprzez ubezpieczenia (ed. A. Wicka). SGGW Publishing House, Warsaw, p. 63.

11. Lorant, A., Farkas, M.F. (2015). Risk Management in the Agricultural Sector with Special Attention to Insurance. Polish Journal of Management Studies, Vol. 11, No. 2, pp. 71-82.

12. Nather, M., Theuvsen, L. (2012). Risikomanagement im Pferdebetrieb. Cuvillier, Goettingen, pp. 14-20.

13. Poole, N. (2017). Risk Management for Agricultural Smallholders. In: Smallholder Agriculture and Market Participation (ed. N. Poole). Food and Agriculture Organization of the United Nations and Practical Action Publishing, Warwickshire, pp. 97-101.

14. Sheldon, I.M. (1996). Contracting, Imperfect Information and the Food System. Review of Agricultural Economics, Vol. 18, pp. 7-19.

15. Stepień, S. (2007). Znaczenie specjalizacji w ksztaltowaniu dochodow rolniczych. In: Uniwersalia polityki rolnej w gospodarce rynkowej. Ujecie makro-i mikroekonomiczne (ed. A. Czyzewski). Publishing House of Akademia Ekonomiczna, Poznan, pp. 209-230.

16.Szemberg, A. (1997). Przemiany agrarne w latach 1992-1996. Zagadnienia Ekonomiki Rolnej, No. 4-5, p. 12.

17. Theuvsen, L. (2013). Risks and Risk Management in Agriculture. Department of Agricultural Economics and Rural Development, Georg August University of Goettingen, Goetingen, pp. 162-174.

18. Tomczyk, E. (2011). Oczekiwania w ekonomii. Oficyna Wydawnicza SGH, Warsaw.

19. Tropea, F. (2016). New Income Stabilization Tools and Price Volatility in Agricultural Markets. European Parliamentary Research Service, Brussels, pp. 6-8.

20. Wojewodzic, T. (2015). Srodowiskowe aspekty likwidacji drobnych gospodarstw rolnych - zarys problemu (presentation). Ministry of Agriculture and Rural Develompnet, Krakow.

21.Zegar, J.S. (2012). Rola drobnych gospodarstw rolnych w procesie spolecznie zrownowazonego rozwoju obszarow wiejskich. Problems of Small Agricultural Holdings, No. 1, pp. 129-148. 